\title{
STATISTICAL ANALYSIS OF BANGLADESH EDUCATION SYSTEM BEFORE AND AFTER COVID 19
}

\author{
Mohammad Mizanur Rahman \\ 2035010660, Business Statistics (BUS-511), Department of Master of Business Administration, \\ North-south University
}

Article DOI: https://doi.org/10.36713/epra8064

DOI No: 10.36713/epra8064

\begin{abstract}
Our Bangladesh education system has been worse after the covid 19 pandemics as today's world is highly interconnected. The severe risk is the outbreak of this virus is not limited to the national border rather worldwide. It has created extreme unfavorable pressure regardless of education level, gender or income. In this research paper, our main objective was to discover the condition of the Bangladesh education system before and after the pandemic. In our country, after the surge of covid 19, the outcome of the unemployment problem, Cost of education, academic performance, Quality of teaching, has been altered undoubtedly. The data was collected from students of Dhaka and Chittagong cities. In our study, 52\% of respondents were male, and $48 \%$ were male. The age proportion of the majority of the students (57\%) is from 20-30. The education level of $85 \%$ of respondents is Graduation and Post-graduation. $48 \%$ of respondents are satisfied current education system of Bangladesh, but $40 \%$ of respondents are not satisfied as they perceive that the current education system of Bangladesh needs to be changed. Independent variables have been selected for this research. Our prominent was to identify how the variables impacted Bangladesh education system In Chittagong city, $57 \%$ of respondents believe that after the COVID pandemic, the Cost of education has been decreased.

On the other hand, in Dhaka city, $67 \%$ of respondents convince that the Cost of education was declined. In the lockdown period, 50\% of students of Chittagong city had spent most of the valuable time developing skills, whereas $34 \%$ of students in Dhaka city spent their time developing skills.

For descriptive statistics, Bar chart, column chart, pie chart, etc., was used. For inferential statistics, Minitab and Excel were used. All of the three variables are categorical. A Chi-square test was performed to estimate the relationship between variables Bangladesh education systems.
\end{abstract}

KEYWORDS: Worse, COVID 19 pandemic, Unemployment, Unethical

\section{INTRODUCTION}

After the outbreak of the COVID pandemic, the education system of Bangladesh has also been disrupted; the rural areas of Bangladesh are facing severe trouble because of internet access and connectivity. The HSC candidates of 2020 observed an unexpected scenario. Most of the students have not been achieved the expected result. Most of the students have been facing uncertainty about their prospects because of the lockdown of international universities by which they are not allowed to go abroad for higher studies. According to this study, around $80 \%$ of students apply unethical practices during the time of exams. Approximately $60 \%$ of people believe that the online teaching evaluation method is not practical. Because of long days, confinement students might get intimidated for study as around $40 \%$ of students are despite studying properly passing their time on entertainment.
Suppose, the government of Bangladesh takes the initiative for educational institutions to remain open. In that case, students will be able to participate in numerous extra-curricular activities and get the opportunity to do class interactively. On the other hand, lower-level-income families are going through a massive challenge because of the economic downturn in Bangladesh. The students who belong to those families might get dropout from the study because of a lack of financial solvency.

\section{OBJECTIVES}

Primary Objective

The primary objective of our report is to study Statistical analysis of Bangladesh educational system before \& after the Covid pandemic situation. Considering the pandemic situation, we have a drastic change in our educational system $\&$ here. This 
pandemic situation is the primary variable that hit the education system directly, such as:

- Traditional class method

- Lack of proper funding in private educational institutions

- Regular salary \& layoff the teachers \& staffs

- Facing difficulties in exam methods \& time

- The Quality of education is low etc.

\section{Secondary Objective}

This report can also be used,

a) To understand the whole educational system to identify \& differentiate before \& after the COVID situation.

b) To understand the updated educational system.

c) To measure the Quality of our present educational system

d) To know all the variables affected to the educational sector

\section{BACKGROUND INFORMATION}

Chittagong: Chittagong city is the port city of Bangladesh and the second-largest city in the country. The population of Chittagong City is more than 8.6 million. The city is situated on the banks of the Karnaphuli River between the Chittagong Hill Tracts and the Bay of Bengal.

Dhaka: The capital city of Bangladesh is Dhaka, and a densely populated city, around 8.9 million residents are currently living here. Dhaka city is famous for the economic, political, cultural center of Bangladesh and also the most numerous cities among the Bay of Bengal countries. The town is enclosed by the Buriganga River, Turag River, Dhaleshwari River, and Shitalakshya River.

\section{DATA COLLECTION TECHNIQUE AND PROCEDURE}

To investigate the current education system of Bangladesh and students adaptability with online class moreover, what kind of problems students are facing in the online education system and how way students are passing their valuable moment in the closure of educational institutions, the Google questionnaire form was used which was delivered to 60 random sample people of Dhaka and Chittagong cities, 30 sample size from each town.

For the data analysis procedure, the data was presented in two ways:

Descriptive statistics: For giving and analyzing data into graphs, several graphs such as pie charts, bar charts, column charts were used.

Inferential statistics: According to the objective of the study, the inferential statistics was completed.
Here six independent variables were used. The Bangladesh education system was the dependent variable. The dependent and independent variables were categorical. That is why for the hypothesis test Chi-square test was performed at a 0.05 significance level.

\section{Main variable \\ Dependent Variable \\ Bangladesh education system}

\section{Independent Variable}

Independent variables are not altered or impacted by other variables; we will utilize six independent variables here. Those are enlisted below:

1. Cost of education

2. Academic Performance

4. Quality of education

\section{METHODOLOGY}

We will use numerous methods and statistical techniques to analyze the results of our study. We are going to select inferential statistics to administer our research project. Pie charts, bar charts, histogram line charts, and lots of statistical techniques will be utilized to analyze the data in our studies. One Dependent variable and six independent variables will be included to carry out the research.

\section{Primary source}

For collecting our primary level data, we need to undergo an inferential cross-sectional survey; In order to conduct a cross-sectional survey, we will pick at least 60 randomly selected people from different areas of Chittagong and Dhaka city. The viewpoint and vision will be accumulated through questionnaires by applying a Google form. Our questionnaire will be segmented into two sections:

- The first section will search for information on respondents' age, gender, education level, student satisfaction, and adaptability with online classes.

- The second section will interpret the Bangladesh education system before and after the COVID 19 pandemic and critical factors.

\section{Secondary Source}

We will examine a few published documents on appropriate topics as our secondary sources of data collection. We will have to undergo some websites, journals, relevant articles, and e-books to accumulate our secondary data for the research studies.

\section{RESULTS}

We have collected data from random people from different areas of Dhaka and Chittagong cities. The data was analyzed, edited, and prepared by using Excel, the Minitab software. Several graphs, such as 
pie chart bar chart frequency distribution tables, have been used to present the analysis of data.

Gender of the respondent

Table 1: Gender of the respondent

\begin{tabular}{|c|c|c|c|}
\hline Gender & Frequency & cumulative frequency & percentage \\
\hline Male & 31 & 31 & $52 \%$ \\
\hline Female & 29 & 60 & $48 \%$ \\
\hline Total & 60 & & $100 \%$ \\
\hline
\end{tabular}

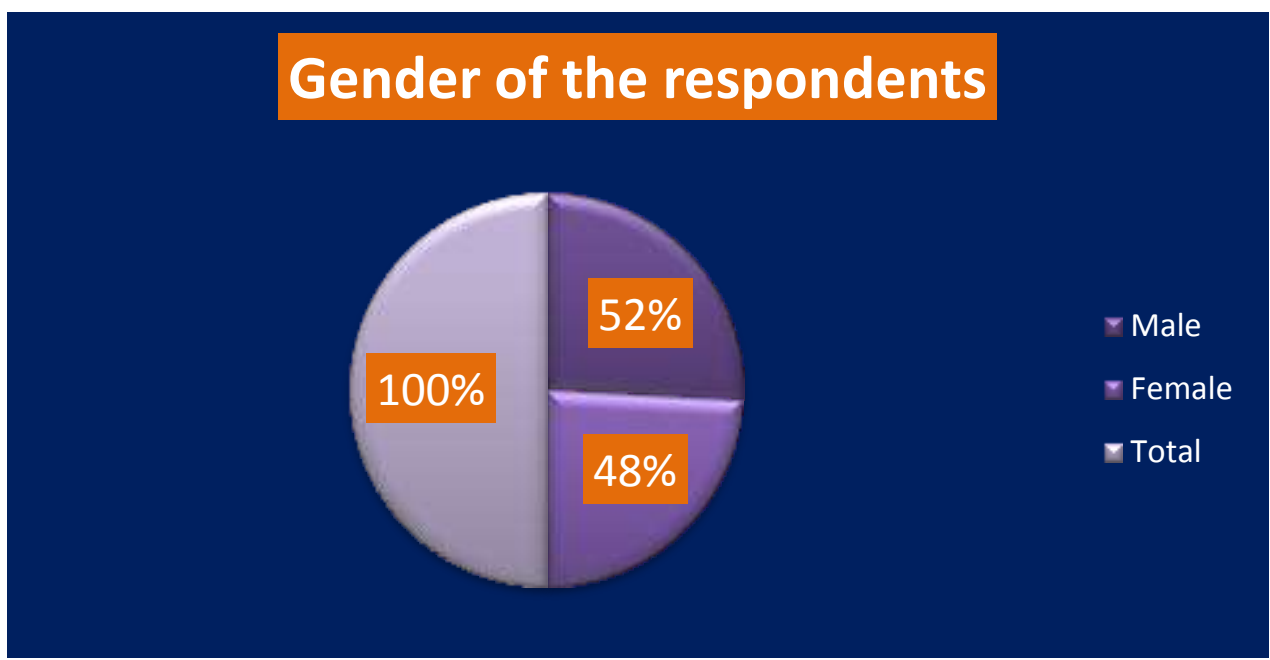

Figure 1: Gender of the respondent

Here the above graph shows that male respondents who were participated in the survey are $48 \%$, alongside $52 \%$ are female.
Age of the respondent

The table below is illustrated the frequency distribution of respondent's ages from the class 20-30 to 50-60. The percentage of the participant is shown in the pie chart.

Table 2: Respondent Age

\begin{tabular}{|c|c|c|c|}
\hline Age & Frequency & cumulative frequency & percentage \\
\hline $20-30$ & 34 & 34 & $57 \%$ \\
\hline $30-40$ & 13 & 47 & $22 \%$ \\
\hline $40-50$ & 12 & 59 & $20 \%$ \\
\hline $50-60$ & 1 & 60 & $2 \%$ \\
\hline Total & $\mathbf{6 0}$ & & $\mathbf{1 0 0 \%}$ \\
\hline
\end{tabular}

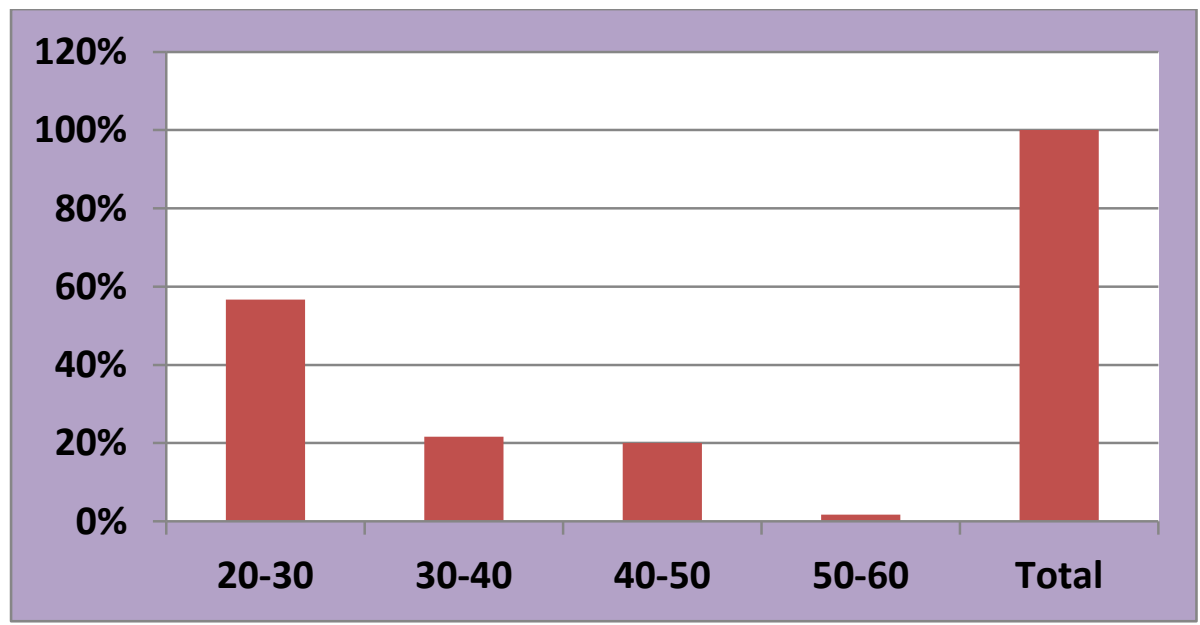

Figure 2: Age of respondents 
The Academic Level of the Respondents

The majority percentage of respondents belongs to Graduation, which is around $45 \%$, approximately
$40 \%$ respondents were graduated students, and the rest of the participants are the highest education level of SSC and HSC. The proportion is $0.2,0.13$.

Table 3: Academic level of the respondents

\begin{tabular}{|c|c|c|c|}
\hline Education Level & Frequency & cumulative frequency & percentage \\
\hline SSC & 1 & 1 & $\mathbf{2 \%}$ \\
\hline HSC & 8 & 9 & $\mathbf{1 3 \%}$ \\
\hline Graduation & 27 & 36 & $\mathbf{4 5 \%}$ \\
\hline Post-Graduation & 24 & 60 & $\mathbf{4 0 \%}$ \\
\hline Total & 60 & & $\mathbf{1 0 0 \%}$ \\
\hline
\end{tabular}

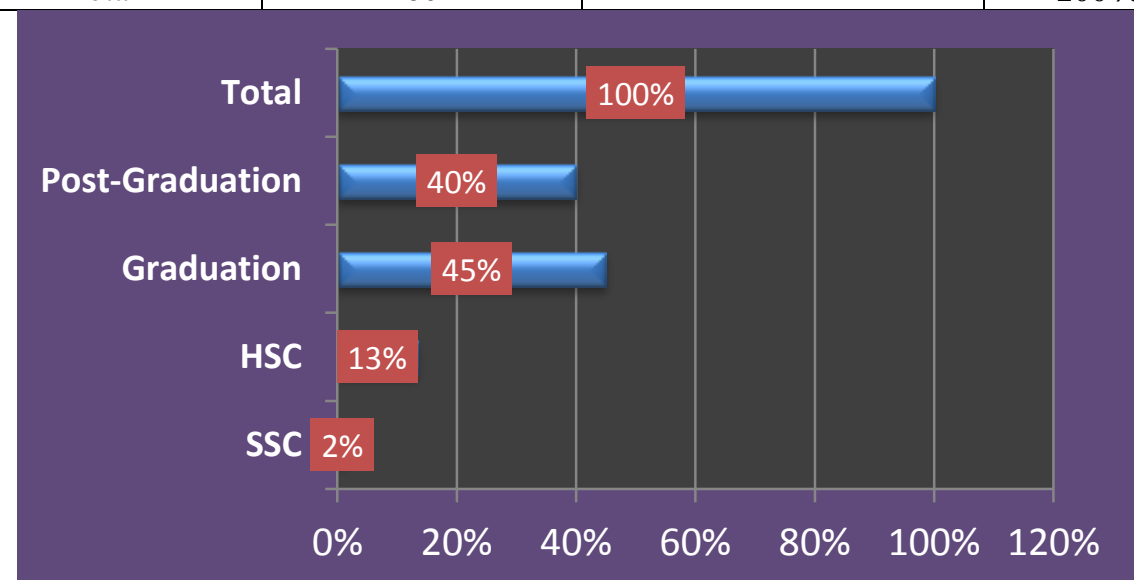

Figure 3: Academic level of the respondents

Satisfaction of Bangladesh Education System

Table 4: Responses about the satisfaction of Bangladesh education system

\begin{tabular}{|c|c|c|c|}
\hline Student Satisfaction & Frequency & Cumulative Frequency & Percentage \\
\hline Yes, but some changes are needed & 29 & 29 & $48 \%$ \\
\hline No, and complete changes are needed & 24 & 53 & $40 \%$ \\
\hline Maybe & 7 & 60 & $12 \%$ \\
\hline Total & 60 & 142 & $100 \%$ \\
\hline
\end{tabular}

\section{Satisfaction of education system}

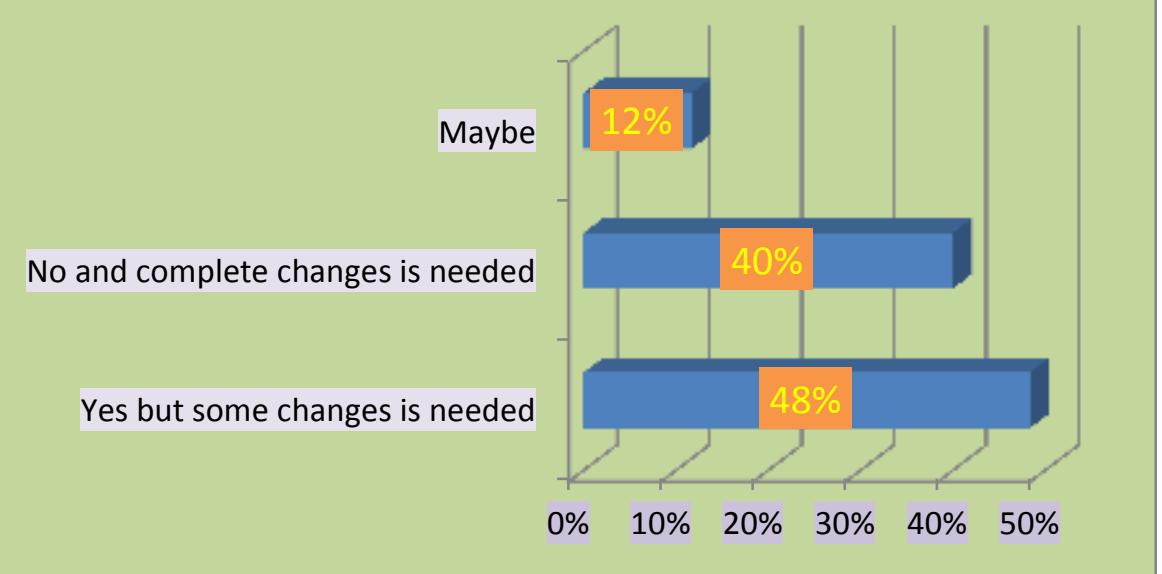

Figure 4: Responses about the satisfaction of Bangladesh Education System 
Interpretation: Here, $48 \%$ of respondents are satisfied with the current education system of Bangladesh, but they expect some changes are needed. $40 \%$ of respondents are not satisfied with the current education system of Bangladesh. They demand complete changes.
Questionnaire from variable "cost of education." Do you think after covid 19 the CostCost of education has been decreased?

Answer: Yes/no

Table: 5 Respondents from Chittagong city about CostCost of education

\begin{tabular}{|c|c|c|c|}
\hline question & Yes & No & Maybe \\
\hline Q1 & 16 & 10 & 4 \\
\hline Percentage & $53 \%$ & $33 \%$ & $13 \%$ \\
\hline
\end{tabular}

\section{Cost of education}

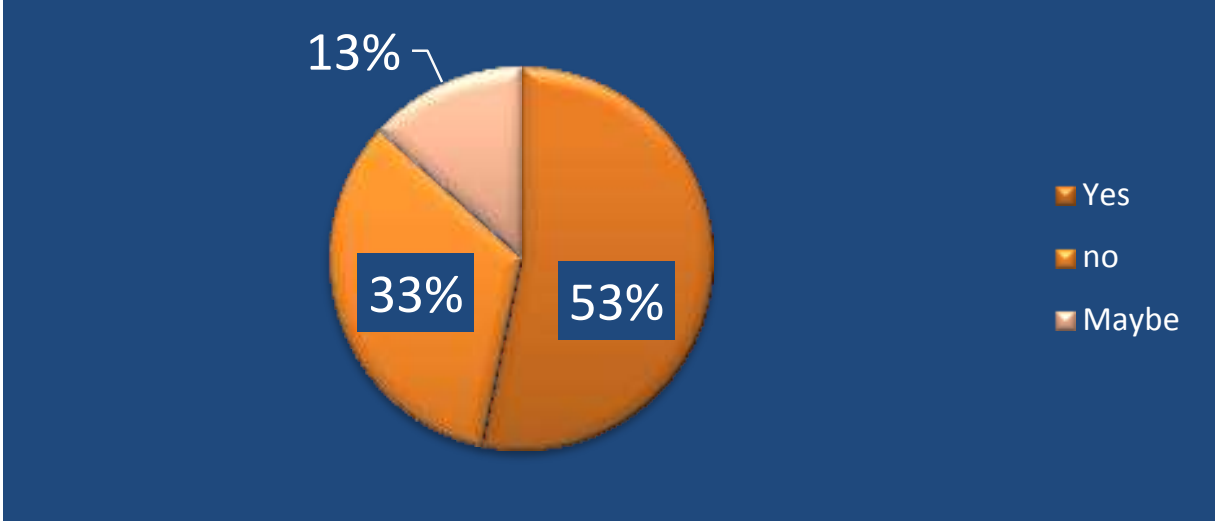

Figure 5: Respondents from Chittagong City about Cost Cost of Education

Interpretation: $53 \%$ of respondents perceive that the CostCost of education has decreased after the covid pandemic, on the other hand, $33 \%$ of respondents consider that CostCost of schooling has remained the same as before. $13 \%$ think that they are not certain about the CostCost of education and 50\% sure and $50 \%$ not sure.

Table 6: Respondent from Dhaka city about Cost of education

\begin{tabular}{|c|c|c|c|}
\hline question & Yes & No & Maybe \\
\hline Q1 & $\mathbf{2 0}$ & $\mathbf{5}$ & $\mathbf{5}$ \\
\hline Percentage & $\mathbf{6 7 \%}$ & $\mathbf{1 7 \%}$ & $\mathbf{1 7 \%}$ \\
\hline
\end{tabular}

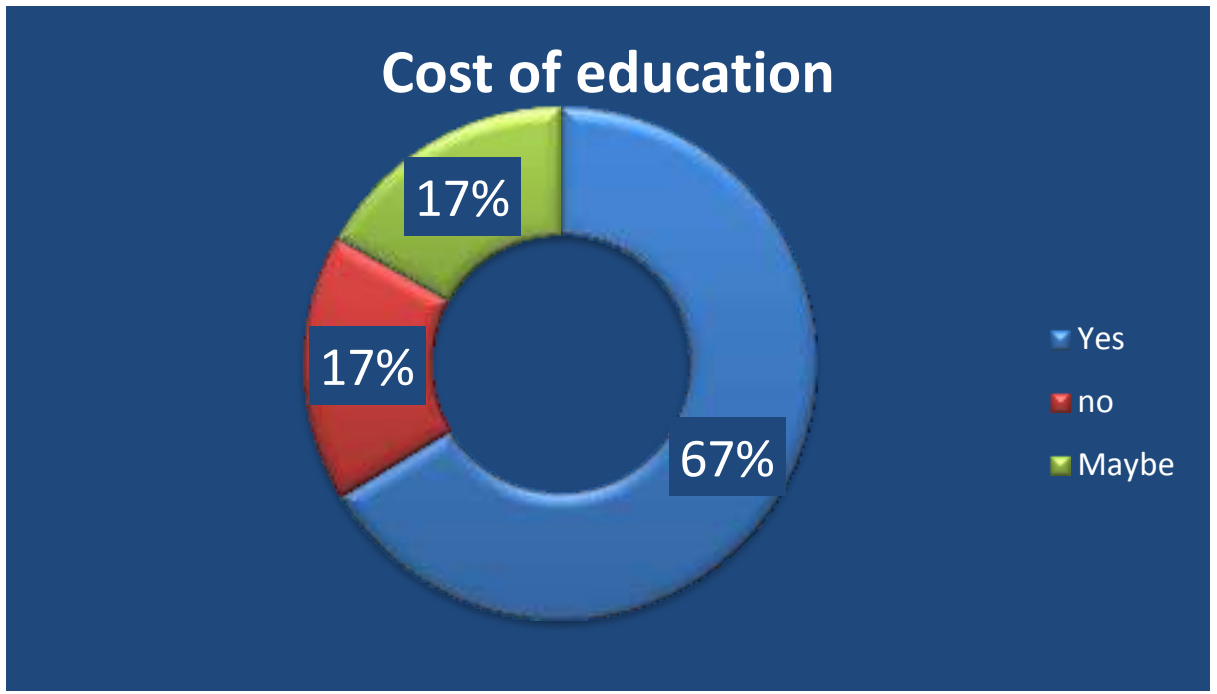

Figure 6: Respondents from Dhaka city about CostCost of education 
Interpretation: $67 \%$ of respondents in Dhaka city think that CostCost of education has been increased after the covid 19 , but $17 \%$ believe that CostCost of education has not been changing .moreover, an equal proportion of people has considered it may be.
Questionnaire for variable "Academic performance."

During the lockdown period, how did you spend most of your valuable time?

Answer: 1. Academic study 2. Developing skills 3.Watching movies 4 . None

Table:7 Response from Chittagong City

\begin{tabular}{|c|c|c|c|c|}
\hline Questions & Academic study & Developing skills & Watching movies & None \\
\hline Q1 & 5 & 15 & 2 & 8 \\
\hline Percentage & $16.67 \%$ & $50.00 \%$ & $6.67 \%$ & $26.67 \%$ \\
\hline
\end{tabular}

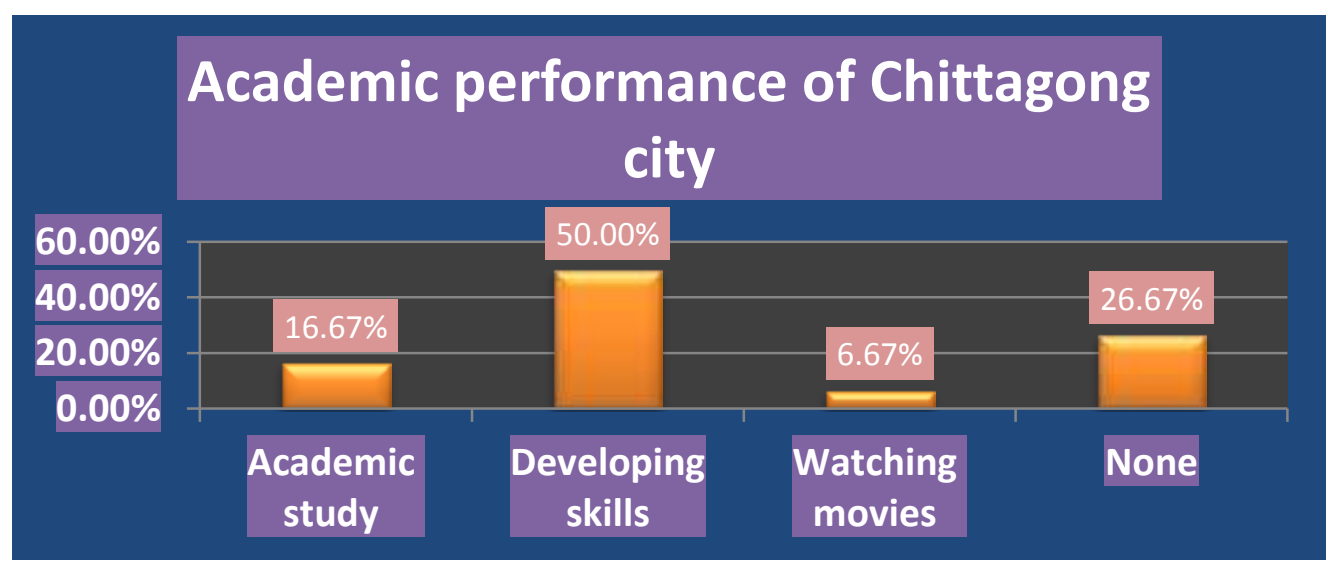

Figure 7: Academic performance of Chittagong city academic performance

Interpretation: $50 \%$ of students of Chittagong city spent most of their valuable time developing skills. Whereas about $16.67 \%$ of respondents are spent their time during the lockdown period by Academic study, approximately $6.67 \%$ by watching movies, $26.67 \%$ of students had not done anything special.

Table: 8 Responses from Dhaka City

\begin{tabular}{|c|c|c|c|c|}
\hline Questions & Academic study & Developing skills & Watching movies & None \\
\hline Q1 & 6 & 10 & 12 & 1 \\
\hline Percentage & $20.70 \%$ & $34.50 \%$ & $41.40 \%$ & $3.40 \%$ \\
\hline
\end{tabular}

\section{Academic performance of Dhaka city}

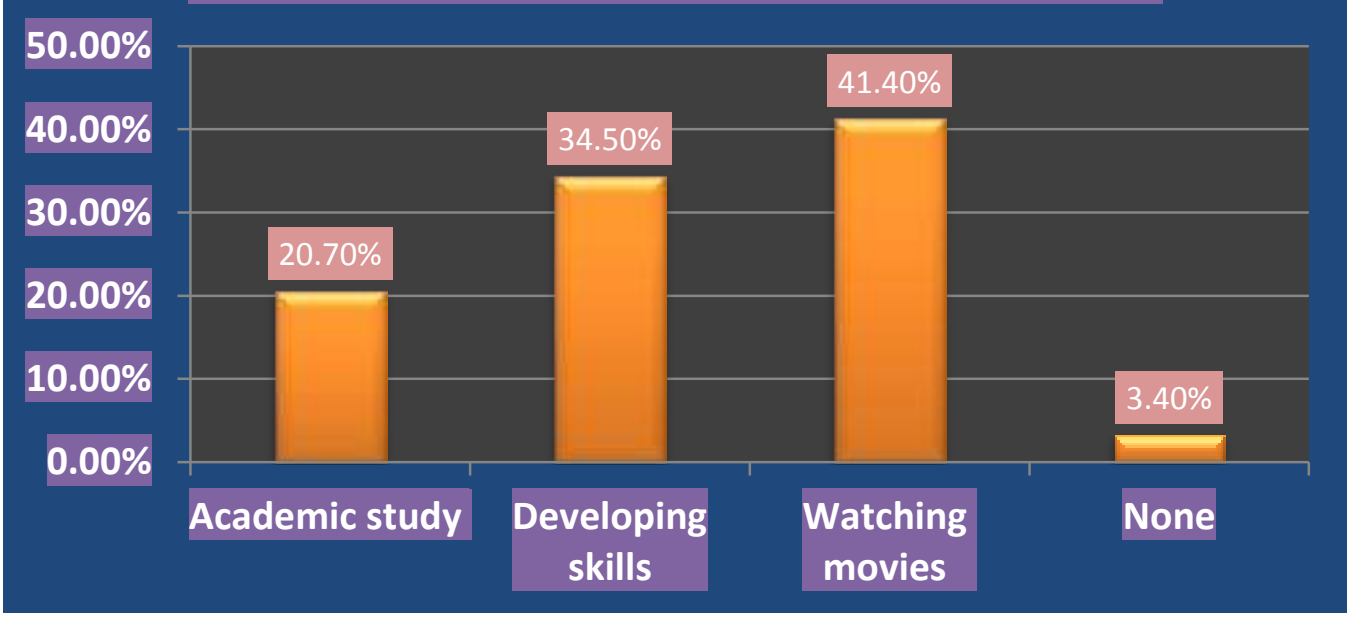

Figure 8: Responses from Dhaka City about Academic Performance 
Interpretation: In Dhaka city, $41.40 \%$ of respondents spend their time during the lockdown period watching movies. On the other hand, $34.50 \%$ of respondents had spent Developing skills, $20.70 \%$ spent by academic study, $3,40 \%$ of respondents had not done anything.
Questionnaire for Variable "Quality of education" The Quality of education has been badly affected after the covid pandemic.

Answer: Strongly

Agree/Agree/Neutral/Disagree/Strongly disagree

Table13: Respondents from Chittagong city about Quality of education

\begin{tabular}{|c|c|c|c|c|c|c|}
\hline Questions & $\begin{array}{c}\text { Strongly Agree } \\
(\%)\end{array}$ & Agree (\%) & Neutral (\%) & Disagree (\%) & $\begin{array}{c}\text { Strongly } \\
\text { Disagree } \\
(\%)\end{array}$ & Total \\
\hline $\mathrm{q} 1$ & 11 & 11 & 3 & 0 & 5 & 30 \\
\hline Percentage & $38 \%$ & $38 \%$ & $10 \%$ & $0 \%$ & $14 \%$ & $100 \%$ \\
\hline
\end{tabular}

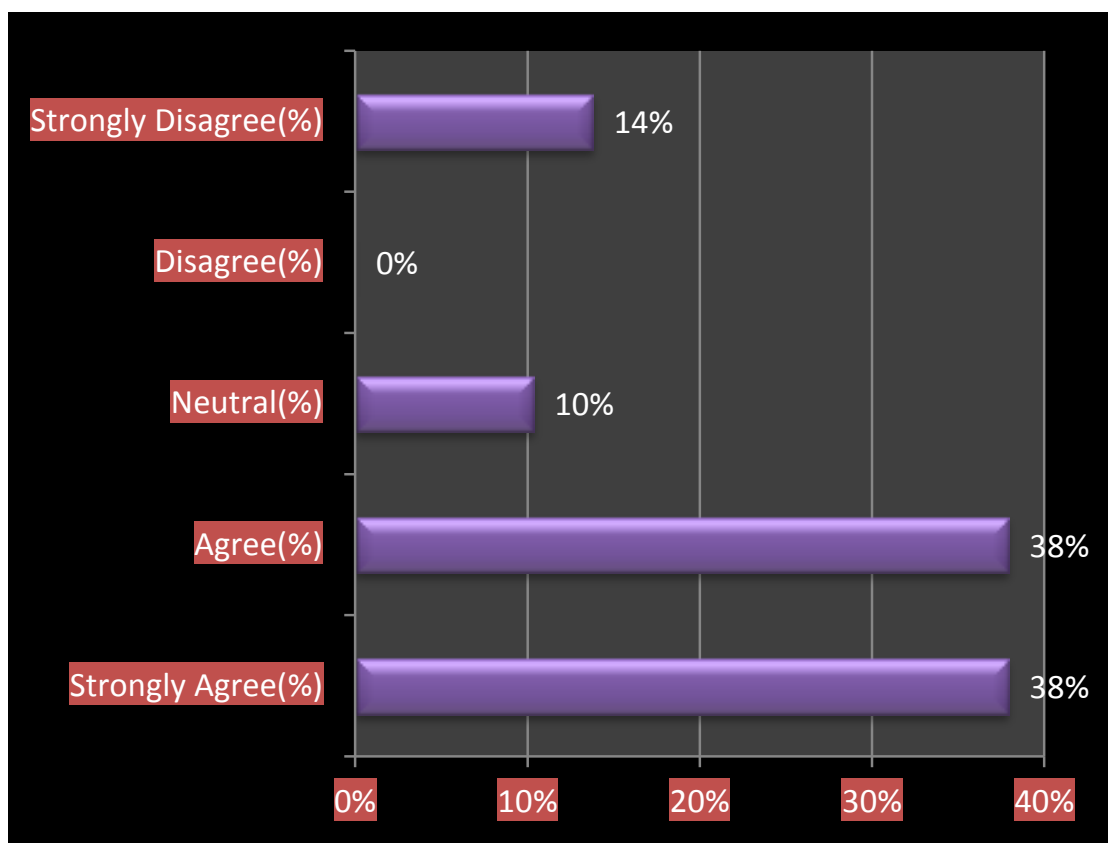

Figure13: Respondents from Chittagong city about Quality of Education

Interpretation: Approximately $76 \%$ of students are agree that the Quality of education after the covid pandemic badly affected.10\% responded with neutral, and 14\% does not agree that the Quality of education has been affected badly.

Respondents from Dhaka city:

Table14: Respondents from Dhaka city about Quality of education

\begin{tabular}{|c|c|c|c|c|c|c|}
\hline questions & $\begin{array}{c}\text { Strongly Agree } \\
(\boldsymbol{\%})\end{array}$ & Agree (\%) & Neutral (\%) & Disagree (\%) & $\begin{array}{c}\text { Strongly } \\
\text { Disagree } \\
(\boldsymbol{\%})\end{array}$ & $\begin{array}{c}\text { Total } \\
\text { Q1 }\end{array}$ \\
\hline Percentage & $47 \%$ & 10 & 2 & 3 & 1 & 30 \\
\hline
\end{tabular}




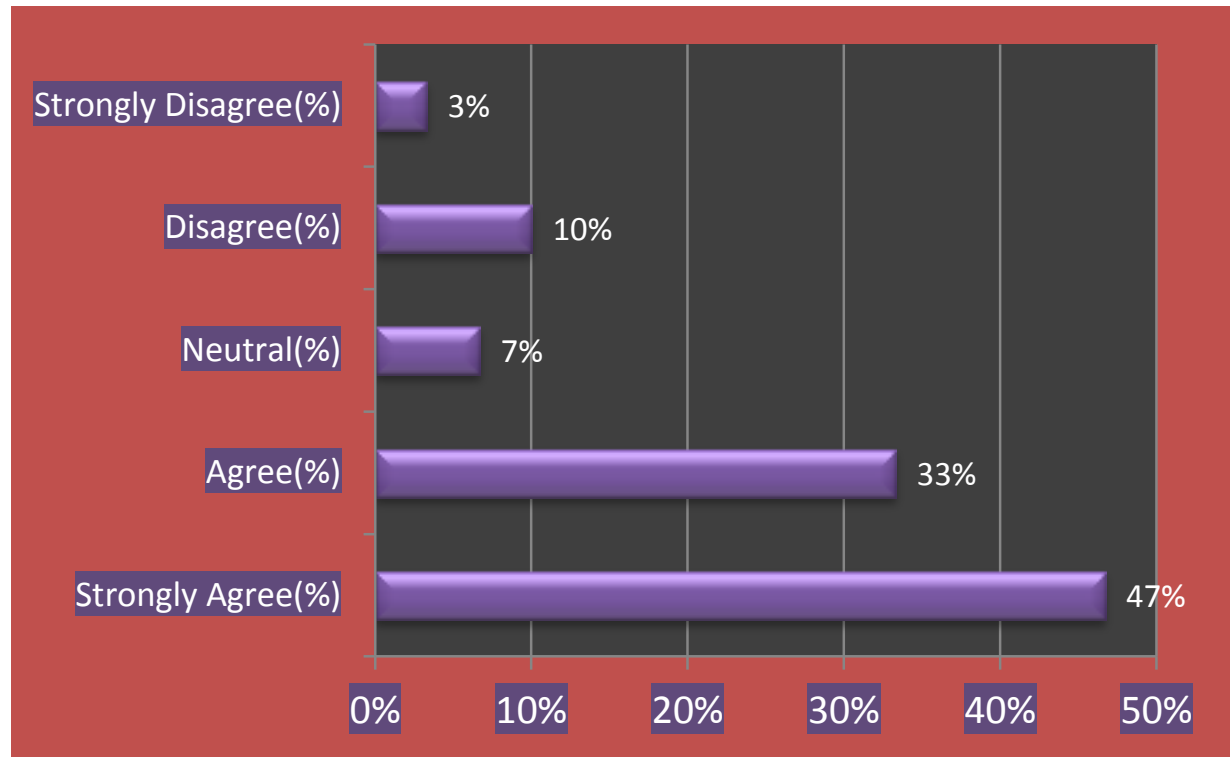

Figure 14: Respondents from Dhaka city about Quality of education

Interpretation: In Dhaka city, most students, 80\%, agree that the Quality of education has been hampered badly. On the other hand, $7 \%$ responded with neutral, Around $13 \%$ disagrees with the statement.

\section{ANALYSIS}

As the dependent and independent variable is categorical, for that reason, the chi-square test was utilized to find out the relationship between factors and Bangladesh education system

\section{Null and alternative hypothesis}

H0: Cost of education is not affected to Bangladesh education system

H1: Cost of education is affected to Bangladesh education system
H0: Academic performance is not affected to Bangladesh education system

H1: Academic performance is affected to Bangladesh education system

H0: Quality of education is not affected to Bangladesh education system

H1: Quality of education is affected to Bangladesh education system

\section{Cost of Education \& Bangladesh Education System}

Here, the Chi-square test method was used at $\alpha 0.05$. The statistic value is greater than critical value $\left(\varkappa^{2}\right.$ $<$ critical value) and $\mathrm{p}<0.329$ by which we can state the decision that the Null hypothesis is not rejected, Cost of education is not affected Bangladesh education system.

Rows: City Columns: Cost of education

\begin{tabular}{|c|l|l|l|l|}
\hline \multicolumn{1}{|c|}{ City } & \multicolumn{1}{|c|}{ Yes } & \multicolumn{1}{c|}{ No } & \multicolumn{1}{c|}{ Maybe } & All \\
\hline & & & & \\
\hline Chittagong & 16 & 10 & 4 & 30 \\
\hline & 18 & 7.5 & 4.5 & \\
\hline & & & & \\
\hline Dhaka & 20 & 5 & 5 & 30 \\
\hline & 18 & 7.5 & 4.5 & \\
\hline \multicolumn{1}{|c|}{ All } & 36 & & & \\
\hline $\begin{array}{l}\text { Cell } \\
\text { Contents } \\
\text { Count }\end{array}$ & & 15 & 9 & \\
\hline
\end{tabular}

Expected count 


\begin{tabular}{|c|c|c|c|}
\hline $\begin{array}{l}\text { Chi-Square } \\
\text { Test }\end{array}$ & & & \\
\hline & Chi-Square & DF & P-Value \\
\hline Pearson & 2.222 & 2 & 0.329 \\
\hline $\begin{array}{r}\text { Likelihood } \\
\text { Ratio }\end{array}$ & 2.256 & 2 & 0.324 \\
\hline
\end{tabular}

\section{Academic Performance \& Bangladesh Education} System

Here, the Chi-square test method was used at $\alpha 0.05$. The statistic value is greater than critical value $\left(\mathcal{\varkappa}^{2}\right.$
$>$ critical value) and $\mathrm{p}>0.003$ by which we can state the decision that the Null hypothesis is rejected, so, Academic performance is affected Bangladesh education system.

Rows: City Columns: Academic performance

\begin{tabular}{|c|c|c|c|c|c|}
\hline \multirow[b]{2}{*}{ City } & Academic & Developing & Watching & \multirow[b]{2}{*}{ None } & \multirow[b]{2}{*}{ All } \\
\hline & study & skills & movies & & \\
\hline Chittagong & 5 & 15 & 2 & 8 & 30 \\
\hline & 5.593 & 12.712 & 7.119 & 4.576 & \\
\hline Dhaka & 6 & 10 & 12 & 1 & 29 \\
\hline & 5.407 & 12.288 & 6.881 & 4.424 & \\
\hline All & 11 & 25 & 14 & 9 & 59 \\
\hline
\end{tabular}

\section{Cell Contents}

Count

Expected count

\begin{tabular}{|r|c|c|c|}
\hline Chi-Square Test & & & \\
\hline & Chi-Square & DF & P-Value \\
\hline Pearson & 13.665 & 3 & 0.003 \\
\hline Likelihood Ratio & & & \\
& 15.203 & 3 & 0.002 \\
\hline
\end{tabular}

\section{Quality of Education \& Bangladesh Education}

\section{System:}

Here, the Chi-square test method was used at $\alpha 0.05$ the statistic value is lower than critical value $\left(\varkappa^{2}\right.$ <critical value) and $\mathrm{p}<0.18$ by which we can state the decision that the Null hypothesis is not rejected, so Quality of education is not affected Bangladesh education system.

Rows: City Columns: Quality of education

\begin{tabular}{|c|c|c|c|c|c|c|}
\hline \multirow[b]{2}{*}{ City } & \multirow{2}{*}{$\begin{array}{c}\text { Strongly } \\
\text { Agree }\end{array}$} & \multirow[b]{2}{*}{ Agree } & \multirow[b]{2}{*}{ Neutral } & \multirow[b]{2}{*}{ Disagree } & Strongly & \multirow[b]{2}{*}{ Al } \\
\hline & & & & & Disagree & \\
\hline Chittagong & 11 & 11 & 3 & 0 & 5 & 30 \\
\hline & 12.5 & 10.5 & 2.5 & 1.5 & 3 & \\
\hline \multirow[t]{2}{*}{ Dhaka } & 14 & 10 & 2 & 3 & 1 & 30 \\
\hline & 12.5 & 10.5 & 2.5 & 1.5 & 3 & \\
\hline All & 25 & 21 & 5 & 3 & 6 & 60 \\
\hline
\end{tabular}

Cell Contents

Count

Expected count 


\begin{tabular}{|c|c|c|c|}
\hline Chi-Square Test & & & \\
\hline & $\begin{array}{c}\text { Chi- } \\
\text { Square }\end{array}$ & DF & P-Value \\
\hline Pearson & 6.274 & 4 & 0.18 \\
\hline Likelihood Ratio & 7.68 & 4 & 0.104 \\
\hline
\end{tabular}

\section{CONCLUSION}

The academics have tremendously messed up, and students are too disappointed to ponder their studies and career because of severe lockdown. Some of the students and teachers are facing some problems in conducting the online class. The study was carried out all-inclusive conditions and perception, challenges of online teaching of SSC, HSC, Graduation, post-graduation level. The situation has been deprived for rural areas students because of financial instability and internet accessibility. The government of Bangladesh comes up with new ideas to handle the current scenario. The paper has not included a broad range of statistical analyses on COVID 19 on the education system and its affected student teachers in Bangladesh. The study tried to gather information about the current situation of education in Bangladesh. Because of the pandemic, the collection of a large amount of data was not possible.

\section{ACKNOWLEDGMENT}

Primarily, by the grace of Allah, I have been able to finish the project on time. I feel bless and offer sincere gratitude and thanks to Allah for an immeasurable blessing that aids me to complete my research paper on time.

I feel inclined to exhibit my profound appreciation to my research supervisor, Dr. Kai's zaman ( professor, Department of Industrial \& Production Engineering, Bangladesh University of Engineering and Technology, Dhaka, Bangladesh), who contributed to help me to carry out my research paper with adequate instruction for solving critical problems and finish the report most quickly and effectively. He instructed me on the methodology to use in a research paper and numerous statistical tools to solve practical problems in business.

The research work enabled us to acquire the knowledge of statistical tools used for data analysis and decision-making in real-life problems.

\section{REFERENCES}

1. Tabassum, M. , Mannan, S., Parvez, Md, I. , Ahmed, F.(2021). Online Education during COVID -19 in Bangladesh: University Teacher's Perspective. Aquademia, 5(1), ep21005. https://doi.org/10.21601/aquademia/9611

2. Emon, E. K. H., Alif, A. R., \& Islam, M. S. (2020). Impact of COVID-19 on the Institutional Education System and its Associated Students in Bangladesh. Asian Journal of Education and Social Studies, 11(2), 34-46. https://doi.org/10.9734/ajess/2020/v11i230288

3. Md Mostafizur Rahman, Saadmaan Jubayer Khan, Mohammed Sadman Sakib, Md Abdul Halim, Md Moshiur Rahman, Asikunnaby \& Jannate Mehjabin Jhinuk (2021): COVID-19 responses among university students of Bangladesh: assessment of status and individual view toward COVID-19, Journal of Human Behavior in the Social Environment, DOI: 10.1080/10911359.2020.1822978

4. Chittagong (2021, may 20). In Wikipedia. https://en.wikipedia.org/wiki/Chittagong

5. Dhaka (2021. May 22). In Wikipedia. https://en.wikipedia.org/wiki/Dhaka 